\section{La-Crosse-Viren (LACV)}

\section{W. Stöcker}

Euroimmun Medizinische Labordiagnostika AG, Lübeck, Deutschland

\section{Englischer Begriff La Crosse virus}

Beschreibung des Erregers Familie: Bunyaviridae; Gattung: Bunyavirus; Art: La-Crosse-Virus. Minusstrang-RNAGenom, behüllt, 90-100 nm Durchmesser.

Erkrankungen Vorkommen: USA.

Vektoren: Stechmücken (Ochlerotatus triseriatus, Culex und Aedes sp.).

Wirt: Nager (Eichhörnchen, Streifenhörnchen) dienen als natürliches Virusreservoir, Menschen als Endwirt.

Klinik: La-Crosse-Enzephalitis (Synonyme: Kalifornische Meningitis, kalifornische Meningoenzephalitis); gilt in den USA als eine der häufigsten viralen Enzephalitiden bei Kindern; nur ein kleiner Anteil der Fälle zeigt Symptome (Fieber, Kopfschmerz, Übelkeit, Nackensteife, Lethargie, Enzephalitis, Epilepsie, Paresen), dann sind neurologische Langzeitfolgen möglich (Epilepsie, mentale Störungen, Verhaltensauffälligkeiten); die Letalitätsrate liegt unter $1 \%$.

\section{Analytik}

Direktnachweis: Nachweis viraler RNA durch RT-PCR (Polymerase-Kettenreaktion), Virusanzucht.

Serologie: Nachweis spezifischer Antikörper (IgM, IgG) im Serum durch indirekte Immunfluoreszenz ( $\triangleright$ Immunfluo- reszenz, indirekte); $\triangleright$ Enzyme-linked Immunosorbent Assay (ELISA) oder $\triangleright$ Neutralisationstest.

\section{Probenmaterial}

Direktnachweis: Blut und Blutbestandteile, Gewebe oder Liquor. Das Material sollte bis zur Weiterverarbeitung bei +4 bis $+8{ }^{\circ} \mathrm{C}$ aufbewahrt werden.

Serologie: Serum oder Plasma für den Nachweis der Antikörper sind bei $+4{ }^{\circ} \mathrm{C}$ bis zu 2 Wochen lang beständig, bei $-20{ }^{\circ} \mathrm{C}$ über Monate und Jahre hinweg. Zur Tiefkühlkonservierung des IgM kann man den Proben $80 \%$ gepuffertes Glyzerin beifügen.

Diagnostische Wertigkeit Nur während der virämischen Phase, die beim Menschen als sehr kurz eingeschätzt wird (1-3 Tage), ist der direkte Virusnachweis möglich. Die Diagnose basiert jedoch in der Regel auf dem Nachweis spezifischer IgM bzw. einem signifikanten IgG-Titeranstieg in einem Antikörpernachweissystem (indirekte Immunfluoreszenz, ELISA).

Differenzialdiagnose: Herpes-simplex-Virus-Enzephalitis.

\section{Literatur}

Bennett RS, Cress CM, Ward JM, Firestone CY, Murphy BR, Whitehead SS (2008) La Crosse virus infectivity, pathogenesis, and immunogenicity in mice and monkeys. Virol J 5:25

Hollidge BS (2010) Arboviral encephalitis: transmission, emergence, and pathogenesis. J NeuroImmune Pharmacol 5(3):428-442 